\title{
Determinants of attendance frequency to flamenco shows in Spain. A cultural economic approach
}

\author{
HEREDIA-CARROZA, JESÚS \\ Chair on Competition Policy \\ Department of Economics and Economic History \\ Universidad de Sevilla \\ Correo electrónico: jhercar12@gmail.com \\ PALMA MARTOS, LUIS \\ Chairman on Competition Policy \\ Department of Economics and Economic History \\ Universidad de Sevilla \\ Correo electrónico: 1palma@us.es \\ MARÍN, AlEJANDRO \\ Chair on Competition Policy \\ Department of Economics and Economic History \\ Universidad de Sevilla \\ Correo electrónico: alexbmeist@gmail.com
}

\begin{abstract}
This article aims to determine which variables have effect on the attendance frequency to live flamenco shows. Firstly we have done interviews to flamenco and music industry experts to achieve new-fangled variables in our analysis. Secondly, these variables were valued by flamenco consumers through surveys. Afterwards, with these data, we used a methodology based on different econometric models to obtain the coefficients of the variables. The results show how variables such as educational level, the way the music is listened or the valuation of the performer, amongst others, have an influence on the attendance frequency to flamenco live shows. The article contributes to the scarce empirical literature relating attendance frequency determinants to traditional popular genres by adding never studied before variables, focusing on the flamenco case.
\end{abstract}

Keywords: live music, attendance frequency, traditional popular music, flamenco, Spain. JEL classification: C2; D2; Z1.

MSC2010: 00A65; 00A66.

Artículo recibido el 26 de noviembre de 2018 y aceptado el 8 de marzo de 2019. 


\title{
Determinantes de la frecuencia de asistencia a espectáculos de flamenco en España. Un enfoque económico cultural
}

\begin{abstract}
RESUMEN
Este artículo tiene como objetivo determinar qué variables tienen efecto en la frecuencia de asistencia a los espectáculos de flamenco en vivo. En primer lugar, hemos realizado entrevistas a expertos de la industria del flamenco y la música para lograr nuevas variables en nuestro análisis. En segundo lugar, estas variables fueron valoradas por los consumidores de flamenco a través de encuestas. Posteriormente, con estos datos, utilizamos una metodología basada en diferentes modelos econométricos para obtener los coeficientes de las variables. Los resultados muestran cómo variables como el nivel educativo, la forma en que se escucha la música o la valoración del intérprete, entre otros, influyen en la frecuencia de asistencia a los espectáculos de flamenco en vivo. El artículo contribuye a la escasa literatura empírica que relaciona los determinantes de frecuencia de asistencia con los géneros populares tradicionales, al agregar variables nunca antes estudiadas, centrándose en el caso del flamenco.
\end{abstract}

Palabras clave: música en vivo, frecuencia de asistencia, música popular tradicional, flamenco, España.

Clasificación JEL: C2; D2; Z1.

MSC2010: 00A65; 00A66.

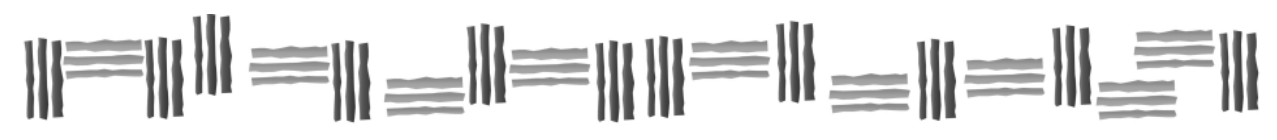




\section{Introduction.}

Cultural participation is a complex activity determined by a series of economic, social and personal factors (Lazzaro \& Frateschi, 2017) that aims to increase of cultural heritage and individual knowledge (Aguado \& Palma, 2015). This has a direct effect on the tastes of the people, increasing the consumption of products whose main characteristics are creativity and innovation (Michael \& Becker, 1973; Bourdieu, 1984; Levy-Gaboua \& Montmarquette, 1996; HerediaCarroza, Pulido \& Palma, 2017).

Flamenco is a traditional popular genre that has its origin in the 18th century in the region of Andalusia (Spain) (Infante, 1980; Cruces, 2001; Aoyama, 2009). Its richness and variety can be observed from a two-sided perspective: on the one hand, the mix of cultures that characterizes it - Andalusian, Roma, Arabic, Jewish- (Romero, 1996; Steingress, 2007), and, on the other hand, its main artistic manifestations such as cante -vocal music-, toque -instrumental music- and baile -the art of dancing (Manuel, 2010; Palma et al., 2017).

According to the above, the aim of this article is to identify the variables that determine the frequency of attendance to live flamenco shows. To achieve this, we made a review on cultural participation literature (Ateca-Amestoy, 2008; Palma et al., 2013; Falk \& Katz-Guerro, 2016; Guccio et al., 2017), as well as, 15 interviews to flamenco and the Spanish music industry experts, in order to identify which variables are linked to the decision of attending flamenco live shows. The duration of the interviews was from 60 to 90 minutes long, and they were carried out in the January-May period of 2017. The selection criteria of the interviewees were their relevance taking into account the awards received in the case of artists; the festivals arranged in the case of cultural managers; or the responsibility level about culture-related themes. In the Appendix I, the panel of experts interviewed is presented.

Regarding this information, we designed a survey, which was answered by flamenco consumers (Aoyama, 2007; Malthouse \& Calder, 2002; Bermúdez, Medina \& Aguado, 2016).

The empirical analysis starts from a database built ad hoc from the 580 surveys obtained (Montoro-Pons \& Cuadrado-García, 2011; Lundy \& Smith, 2016; Au, Ho \& Chan, 2016). With these data, we use the methodology of ordinary least squares, following the thesis proposed by Ferrer-i-Carbonell and Frijters (2004). To complement such methodology and show the robustness of the appraisals raised, an ordered logistic model and another of robust least squares have been taken into consideration.

The article contributes to literature about cultural participation in three aspects:

1. It is the first research about cultural participation focused on a traditional popular music genre like flamenco, which has a sample composed entirely by people that consider themselves to be consumers of it.

2. The effect that has series of newfangled variables, concerning the frequency of assistance, and that has not been treated before in other investigations, is identified. These variables comprise the performer, the author, the structural music elements, and the way of listening, fashions, among others.

3. From a methodological perspective, with the results obtained, it is proved that an ordinary least squares model, under the assumption of cardinality, yields results that are equivalent in a significant way to discrete choice models.

The article is organized in the following sections: "data and variables", where an explanation about the information gathering and the variables used in the study will be found. Below is a reference made to the methodology used and the results obtained (Helliwell \& Huang, 
2008; Borra \& Gómez-García, 2012). An epigraph will be dedicated to the discussion of the results and, by last, the conclusions will be added.

\section{Data and variables.}

The development of this epigraph holds the process of gathering qualitative information obtained through interviews to flamenco and the Spanish music industry experts, and later presents the quantitative information obtained from the 580 surveys made to flamenco consumers.

\section{Interviews.}

In order to identify which variables have an effect on the attendance to live shows, in addition to the already existing bibliography (Zanola, 2010; Hallmann et al., 2017; Lenguina \& Miles, 2017; Borowiecki \& Marvao, 2017), 15 of the most outstanding flamenco and the Spanish music industry personalities have been interviewed (Arboleda \& Gonzalez, 2016; Hernando \& Campo, 2017; Heredia-Carroza, Palma \& Aguado, Forthcoming).

Using the previous bibliography concerning cultural economics as a base (Withers, 1980; Throsby, 1983; Towse, 2007; Werck \& Heyndels, 2007; Zieba \& O'Hagan, 2010), the interviews were structured in three parts. Firstly, it is inquired into the structure of the musical piece, the elements that show its cultural value and the elements that affect its success (Hadida, 2010; Heredia-Carroza, 2019). Secondly, a section is dedicated to Copyright and, finally, a general section dedicated to future studies. In the present article, we have used the information obtained in the first part of the interviews (Heredia-Carroza et al., 2019a).

The interviewed personalities are authors, who are as well performers of the three flamenco manifestations -cante, baile and toque-; responsible politicians for the cultural area-Ex-counselor of Culture in Andalusia-; representatives of the two most important Copyright entities in Spain Sociedad General de Autores y Editores (SGAE) and Asociación de Artistas, Intérpretes y Ejecutantes (AIE); or cultural managers of important flamenco festivals such as "Bienal de Flamenco de Sevilla" and the "Festival de Jerez de la Frontera". The questionnaires and the database are available at demand of the authors (Heredia-Carroza et al., 2019b; Heredia-Carroza et al., 2019c).

Finally, joining the variables identified in the bibliography and those given by the interviews, we identified four groups of variables that may have an effect on the frequency of attendance of live flamenco shows:

- Sociodemographic: age, educational level or gender of the individuals. These variables help to control the heterogeneity among individuals decreasing the relevance of potential variables that have been omitted, significantly relevant (Bermúdez et al., 2016; Andrade, 2016).

- Variables referring to the flamenco cultural capital of the individual (Ateca-Amestoy, 2009): time consuming flamenco, number of albums acquired, the platform where it is usually listened to or the atmosphere in which the taste for it was created (Borowiecki \& Marvao, 2017).

- Variables that characterize the individual's behavior: whether she attends shows concerning other musical genres or not (Holbrook \& Hirschman, 1982; Holbrook, 1999), or if she supports the public financing of flamenco (Palma \& Aguado, 2011).

- Variables that express which elements of the flamenco work are most valued by the individual (Klamer, 2003; Levison, 2015): its structural elements (harmony ${ }^{3}$, rhythm, 
melody and lyrics) (Rosón, 2010; Heredia-Carroza, Palma \& Aguado, 2017), the agents that create the work (author, performer), awards recieved, place where it is performed, fashions or tickets selling, among others (Heredia-Carroza et al., 2019b). We note that the variable "harmonics" is omitted from the econometric model, due to collinear problems with the variable melody. This makes sense in the musical theory, since the melody carries a harmony congruent with it. It has been chosen to maintain the melody because it is an easier element to be recognized and differentiated by the fans regardless of their degree of musical knowledge.

\section{Descriptive statistics from surveys.}

Once the different groups of variables were identified, surveys were carried out between May and July 2017 by means of an online survey instrument stipulated on Flama. La guía del flamenco (information portal, ticket sales, entertainment agenda and news about flamenco, that operates in Spain and France on a monthly basis since January 2006), that also had the disclosure of the Centro Andaluz de Documentación del Flamenco and the Promocionmusical.es website (HerediaCarroza et al., 2019c).

The survey was divided in four parts. On the first one, the flamenco consumers' habits were inquired. On the second part, questions on the elements of the flamenco work were proposed. On the third one, affairs concerning cultural politics were studied, making questions on whether flamenco should be supported by public funds or not. On the fourth part, we require basic sociodemographic aspects. Finally, 580 surveys from people that considered themselves to be flamenco consumers. The first question of the survey was: What is your relationship with flamenco? Where several options were given, such as consumer. For the present study, we have used the data obtained that fall into this category. In Table 1, the variables used in the later econometric analysis are presented.

Table 1. Statistical descriptions of the selected variables.

\begin{tabular}{|c|c|c|c|c|c|}
\hline Variable & N. Obs & Mean & St. Desv. & Min & Max \\
\hline \multicolumn{6}{|l|}{ Dependent Variable ${ }^{1}$} \\
\hline Frequency of attendance to live flamenco shows & 451 & 3.12 & 1.58 & 1 & 5 \\
\hline \multicolumn{6}{|c|}{ Variables referring to the sociodemographic characteristics of the individual } \\
\hline Male & 580 & 0.54 & 0.5 & 0 & 1 \\
\hline Female & 580 & 0.46 & 0.5 & 0 & 1 \\
\hline Less than 30 years old & 580 & 0.28 & 0.45 & 0 & 1 \\
\hline 30-39 years old & 580 & 0.22 & 0.42 & 0 & 1 \\
\hline $40-49$ years old & 580 & 0.19 & 0.4 & 0 & 1 \\
\hline 50-59 years old & 580 & 0.18 & 0.39 & 0 & 1 \\
\hline More than 60 years old & 580 & 0.12 & 0.32 & 0 & 1 \\
\hline Non-educational level & 580 & 0.0310345 & 0.1735606 & 0 & 1 \\
\hline Primary school level & 580 & 0.1189655 & 0.3240274 & 0 & 1 \\
\hline Secondary level & 580 & 0.1706897 & 0.3765623 & 0 & 1 \\
\hline Pre-college level & 580 & 0.1396552 & 0.3469281 & 0 & 1 \\
\hline University level & 580 & 0.5396552 & 0.4988552 & 0 & 1 \\
\hline \multicolumn{6}{|l|}{ Flamenco cultural capital of the individual ${ }^{2}$} \\
\hline Number of albums acquired & 580 & 2.07 & 1.09 & 1 & 4 \\
\hline She usually listens to flamenco on radio or TV & 578 & 0.13 & 0.34 & 0 & 1 \\
\hline She usually listens to flamenco on recorded music & 578 & 0.29 & 0.45 & 0 & 1 \\
\hline She usually listens to flamenco on live shows & 578 & 0.1 & 0.3 & 0 & 1 \\
\hline
\end{tabular}


She usually listens to flamenco via streaming

She usually listens to flamenco on YouTube

She does not usually listen to flamenco

She developed by herself, her taste for flamenco

Her family made her develop a taste for flamenco

Her friends made her develop a taste for flamenco

Her couple made her develop a taste for flamenco

A taste for flamenco was not developed

\section{Variables that characterize the behavior of the individual ${ }^{3}$}

She has attended presentations of other musical genres

She has not attended presentations of other musical genres

She agrees with the public financing of flamenco

She does not agree with the public financing of flamenco

\section{Assessment variables on the flamenco work}

She values the melody of the work

She values the rhythm of the work

She values the lyrics of the work

She values the author

She considers the performer to be essential to the work

She values that the work is on trend

She values the theater where the work is performed

She values the awards the work has

She values that the upper sale of tickets and the upper recognition

${ }^{1}$ Not all the surveyed people answered this question.

${ }^{2}$ For these questions, the option does not know/does not answer was added, that is why there are not 580 answers.

${ }^{3}$ For these sort of variables, as well as using a 7-points Likert scale, the option does not know/does not answer was added, that is why there are not 580 answers.

Source of the application: Excel 2013.

Source: Own elaboration.

Once the variables and the obtained descriptive statistics are presented, in the following section the econometric strategy used is shown (di Tella, MacCulloch \& Oswald, 2001; Ferrer-iCarbonell \& Frijters, 2004).

\section{Econometric strategy.}

With the data obtained from the surveys (Choi, Papandrea \&Bennett, 2007; Chan, Au \& Ying, 2016), this article aims to contrast which are the variables that determine the frequency of attendance to live flamenco shows. For this, the empirical strategy is the following one.

The dependent variable of the model is the consumers' frequency attendance to flamenco shows. That variable is expressed in a scale of 5 possible categories, where the individual chooses a path of action from a finite set of options. That way, a variable whose qualitative nature corresponds to the use of discrete choice models -like an ordered logit- is configured. Despite this, there is significant empiric evidence (Ferrer-i-Carbonell \& Frijters, 2004; Borra \& GómezGarcía, 2012) that an ordinary least squares model, under the assumption of cardinality throws equivalent results in a significant way, making it easier the interpretation of the results. For this reason, ordinary least squares model is chosen, complemented by an ordered logit model and a robust least squares one, in order to show the robustness of the estimates raised and the validity of the premise mentioned above. 
The least squares model will be posed in the following way:

$$
Y_{i}=\alpha+\beta_{1} X_{1}+\beta_{2} X_{2}+\beta_{3} X_{3}+\beta_{4} X_{4}+\varepsilon_{i}
$$

where:

- The dependent variable $Y_{i}$ represents the frequency of attendance of the $i$ individual.

- $\alpha$ is the constant.

- $X_{1}$ is the vector for the sociodemographic characteristics of the individual.

- $X_{2}$ is the vector for the flamenco cultural capital of the individual.

- $X_{3}$ is the vector for those variables that characterize the behavior of the individual.

- $X_{4}$ is the vector for the variables expressing which components of the flamenco work are valued by the individual.

- $\varepsilon_{\mathrm{i}}$ is the random disturbance.

\section{Results.}

The results obtained via the triple methodological perspective (OLS, Ordered Logit and Robust OLS) are shown on Table 2.

Table 2. Results obtained.

\begin{tabular}{llll}
\hline $\mathbf{N}^{\mathbf{0}}$ Obs. & 371 & 371 & 371 \\
$\mathbf{R}^{2}$ & 0.289 & & 0.285 \\
Model & $\begin{array}{l}\text { Reg. } \\
\text { Lineal }\end{array}$ & $\begin{array}{l}\text { Ordered } \\
\text { Logit }\end{array}$ & $\begin{array}{l}\text { Reg. } \\
\text { Robusta }\end{array}$ \\
Dependent variable: frequency & & & \\
Time consuming flamenco & $0.270^{* *}$ & $0.483^{* * *}$ & $0.301^{* *}$ \\
& $(0.117)$ & $(0.180)$ & $(0.127)$ \\
Number of albums acquired & $0.173^{* *}$ & $0.191^{*}$ & $0.175^{* *}$ \\
& $(0.0799)$ & $(0.107)$ & $(0.0864)$ \\
Reference: female & & & \\
Male & -0.0963 & -0.143 & -0.114 \\
& $(0.158)$ & $(0.219)$ & $(0.170)$ \\
Reference: less than 30 years old & & & \\
30-39 years old & $-0.367^{*}$ & $-0.513^{*}$ & $-0.411^{*}$ \\
& $(0.219)$ & $(0.307)$ & $(0.237)$ \\
40-49 years old & 0.0943 & 0.112 & 0.143 \\
& $(0.256)$ & $(0.351)$ & $(0.277)$ \\
50-59 years old & $-0.479^{*}$ & -0.576 & $-0.468^{*}$ \\
& $(0.254)$ & $(0.352)$ & $(0.274)$ \\
More than 60 years old & -0.123 & -0.253 & -0.106 \\
& $(0.317)$ & $(0.421)$ & $(0.343)$ \\
Reference: primary school level & & & \\
Non-educational level & -0.753 & -0.861 & -0.689 \\
Secondary level & $(0.483)$ & $(0.699)$ & $(0.522)$ \\
Pre-college level & $-0.529^{*}$ & $-0.941^{* *}$ & $-0.620^{* *}$ \\
& $(0.277)$ & $(0.394)$ & $(0.299)$ \\
& $-0.675^{* *}$ & $-1.039^{* *}$ & $-0.709^{* *}$ \\
& $(0.308)$ & $(0.433)$ & $(0.333)$ \\
& & & \\
& & & \\
& & &
\end{tabular}


University level

$\begin{array}{lll}-0.689 * * * & -1.149 * * * & -0.729 * * * \\ (0.259) & (0.367) & (0.280)\end{array}$

Reference: she usually listens to flamenco on the radio or $T V$

She usually listens to flamenco via recorded music

$\begin{array}{lll}0.703 * * * & 1.100 * * * & 0.824 * * * \\ (0.260) & (0.377) & (0.281) \\ 0.718^{* *} & 1.016 * * & 0.789 * * \\ (0.319) & (0.453) & (0.345) \\ 0.932 * * * & 1.473 * * * & 1.071 * * * \\ (0.319) & (0.462) & (0.345) \\ 0.583 * * & 1.050 * * & 0.696 * * \\ (0.283) & (0.416) & (0.306) \\ 1.122 & 2.144 & 1.242 \\ (-1.472) & (-4.061) & (-1.592)\end{array}$

Reference: she developed by herself her taste for flamenco

Her family made her develop her taste for flamenco

$-0.113 \quad-0.277 \quad-0.150$

$(0.179) \quad(0.243)$

(0.193)

Her friends made her develop her taste for flamenco

$-0.0859-0.116$

$-0.127$

$(0.245) \quad(0.331)$

(0.264)

Her couple made her develop her taste for flamenco

$0.806 * \quad 1.557 * *$

0.807

$(0.459) \quad(0.749)$

(0.497)

She did not develop a taste for flamenco

$-1.290 * * \quad-16.71$

$-1.233 * *$

(0.502) (-1.005)

$(0.543)$

Reference: she has not attended presentations on other musical genres

She has attended presentations on other musical genres

$\begin{array}{lll}0.684 * * * & 0.852 * * * & 0.749 * * * \\ (0.165) & (0.241) & (0.179)\end{array}$

Reference: she does not agree with the public financing of flamenco

She agrees with the public financing of flamenco

\begin{tabular}{lll}
0.485 & 0.668 & 0.493 \\
$(0.306)$ & $(0.454)$ & $(0.331)$ \\
-0.0198 & -0.0425 & -0.0280 \\
$(0.0991)$ & $(0.144)$ & $(0.107)$ \\
0.0411 & 0.0584 & 0.0564 \\
$(0.0873)$ & $(0.126)$ & $(0.0944)$ \\
-0.0466 & -0.0961 & -0.0641 \\
$(0.0603)$ & $(0.0865)$ & $(0.0653)$ \\
-0.0135 & -0.0147 & -0.0115 \\
-0.0377 & -0.0524 & -0.0408 \\
$0.180 * * *$ & $0.251 * *$ & $0.205 * * *$ \\
$(0.0694)$ & $(0.0980)$ & $(0.0751)$ \\
-0.0192 & -0.0470 & -0.0120 \\
$(0.0528)$ & $(0.0736)$ & $(0.0571)$ \\
-0.0153 & 0.0137 & -0.0166 \\
$(0.0572)$ & $(0.0803)$ & $(0.0619)$ \\
0.0285 & 0.0521 & 0.0327 \\
$(0.0564)$ & $(0.0804)$ & $(0.0610)$ \\
-0.0489 & -0.0721 & -0.0576 \\
$(0.0514)$ & $(0.0724)$ & $(0.0556)$ \\
\hline
\end{tabular}

She values the melody of the piece

$-0.0280$

She values the rhythm of the piece

$(0.0991) \quad(0.144)$

(0.107)

$0.0411 \quad 0.0584$

$(0.0944)$

She values the lyrics of the piece

$-0.0466 \quad-0.0961$

$-0.0641$

She values knowing the author of the piece

She considers the performer of the work to be essential

She values that the work is on trend

She values the theater where the work is held

She values the awards the work has

She values the sale of tickets and has recognition 


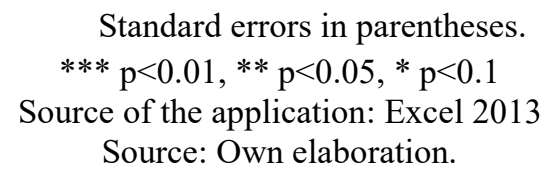

Firstly, from a methodological perspective, it is important to highlight that the coefficients and their importance endorse the hypothesis proposed by Ferrer-i-Carbonell \& Fritjers (2004) of equivalence between linear models and discrete choice models, as well as the robustness of the results. Furthermore, as we have seen in Table 1, the values of the dependent variable range from 1 to 5 with a mean of 3.12 , having some coefficients a relevant effect on that variable.

Concerning the groups of variables, the sociodemographic ones deserve special attention. Gender is not significant, while the educational level and age indeed are. Regarding the age, the interviewed people whose ages range from 30 to 39 years old, as well as those from 50 to 59 years old, attend less often to flamenco live shows in a significant way. With respect to educational level, it is shown that the higher the level, the lesser frequency of attendance.

Those variables related to the flamenco cultural capital of the individual show us that the time consuming flamenco and the number of albums acquired, produce positive effects on the frequency of attendance. On the other hand, the means by which flamenco is usually listened to are profiled as a relevant variable, given that those who listen to flamenco in the above said ways increase their frequency of attendance in a significant way, in comparison to those who listen to flamenco via radio or TV.

Lastly, variables related to the valuing of the flamenco work are the ones that throw the most interesting coefficients regarding the frequency of attendance. Of all the factors considered, the only one that significantly increases that frequency is the consideration of the performer to be an essential figure in the work. While the figure of the author, the structural elements of the flamenco work, the theater where it is held or the recognition of the work by means of awards, tickets selling or experts' critics do not have a significant impact on the frequency.

\section{Discussion of the results.}

Taking into consideration the results of the model, there are some variables such as the time spent listening to flamenco or the number of album acquired show intuitive results (Icazuriaga, Cuadrado \& Miquel, 2016), in other cases the explanation turns out to be needed.

Concerning the sociodemographic variables, the effects of the age and the educational level of the individual are especially interesting. In the different age ranges shown, it is observed that in the 30-39 range, and in the 50-59 range, the attendance to the flamenco shows is significantly lower. In the survey, they were asked about the reasons why they did not attend (Aguado \& Palma, 2015), whose answers are shown in Table 3.

We can observe that the main reason for the non-attendance is, for all the age ranges, the "lack of time", aggravated in the range holding 40 to 59 years, ages in which usually family and job responsibilities are more than in other ranges. In the range holding 30 to 39 years, the most important reasons (as well as the "lack of time") are the "lack of money" and the "ignorance on the existence of shows". Regarding the "lack of money", it may find its explanation, on the one hand, in the actual situation of the labour market (Bande \& Karanassou, 2013; Sala \& Trivin, 2014; Rebollo-Sanz \& García-Pérez, 2015; Jiménez-Martín et al., 2019) and, on the other hand, in the fact that, in an average way, in these age ranges a family starts to be formed and important expenses related to this start to appear (Han, Huang \& Garfinkel, 2003; Hill, 2005).

As regards to the "ignorance on existence of shows", it is a problem of uninformed people, as there are accessible means in order to give disclosure to live shows: Flama, La Guía del 
flamenco is an example of this. It would be necessary to question why this happens. At a first glance, in the research, it was thought that it happened because of a lack of interest, but as it can be observed in Table 3, the rates of disinterest towards flamenco are low in every age range.

Table 3. Reasons for the non-attendance by age ranges.

\begin{tabular}{|c|c|c|c|c|c|}
\hline & $<30$ y. о. & 30-39 y. о. & 40-49 у. о. & 50-59 у. о. & $>60$ y. o. \\
\hline Lack of money & $13.41 \%$ & $14.73 \%$ & $6.25 \%$ & $6.60 \%$ & $5.80 \%$ \\
\hline $\begin{array}{l}\text { Distance of the } \\
\text { show }\end{array}$ & $8.54 \%$ & $12.40 \%$ & $8.93 \%$ & $12.26 \%$ & $27.54 \%$ \\
\hline $\begin{array}{l}\text { Absence of } \\
\text { shows }\end{array}$ & $12.80 \%$ & $13.95 \%$ & $20.54 \%$ & $15.09 \%$ & $15.94 \%$ \\
\hline Lack of time & $25.00 \%$ & $29.46 \%$ & $47.32 \%$ & $42.45 \%$ & $36.23 \%$ \\
\hline $\begin{array}{l}\text { Ignorance of } \\
\text { existence of } \\
\text { shows }\end{array}$ & $29.88 \%$ & $22.48 \%$ & $11.61 \%$ & $17.92 \%$ & $13.04 \%$ \\
\hline $\begin{array}{l}\text { Lack of interest } \\
\text { about flamenco }\end{array}$ & $10.37 \%$ & $6.98 \%$ & $5.36 \%$ & $5.66 \%$ & $1.45 \%$ \\
\hline
\end{tabular}

Concerning the educational level, we can observe in the model how there is a negative effect on the frequency of attendance, therefore, that the higher educational level of the individual, she attends less to flamenco live shows. Taking primary education as a reference, the negative coefficient linked to higher education level is higher and more significant. This is enforced by the study made by De Sancha-Navarro et al. (2019) where it reflects the fact that "the $43 \%$ of the student body of the University of Seville has never attended to a live flamenco shows". It is especially striking that university students in the city of Seville have not attended any show. Seville is considered one of the most important cities worldwide in the flamenco offer (Palma et al., 2017), and has one of the most important international festivals, the "Bienal de Flamenco de Sevilla", held in biannual in the month of September.

Attending to the negative effect that the educational level has on attendance and the reasons for the non-attendance in the age ranges, it should be questioned the role of flamenco in the educational institutions (schools, high schools, universities and conservatoires), and in which way it should be promoted so that the information concerning flamenco live shows reach the " $<30$ to 39" age ranges (Dimoulas et al., 2014; Cuenca, 2016).

One of the most important contributions to the investigation is the analysis of the effect of the way of listening to music has on the frequency of attendance to flamenco live shows (MiquelRomero \& Montoro-Pons, 2017). It has been shown that all the proposed ways increase the frequency of attendance in a significant way in comparison to those who listen to flamenco on the radio or TV. This is due to the fact that the rest of ways implicitly involve the aim of listening to flamenco, while those who listen to it on the radio or TV may have done it by chance. That way shows the higher coefficient is the "via Streaming" one, given that it is a very specific way that entails looking for information about the event and searching the broadcast.

YouTube should also be highlighted, data shows that it is the most often used way for the $31.83 \%$ of the surveyed people (in appendix II, the data in percentages of the media that are normally used by the surveyed flamenco consumer is presented). YouTube is a free platform that brings flamenco closer to their consumers (Bükner \& Lange, 2017). It has been used to spread the works of artists such as Enrique Morente, Cigala or Niña Pastori, among others. 
In the same way, the origin of the taste for flamenco throws interesting results. Regarding those who developed the taste by themselves (Hallmann et al., 2017), only those whose taste has its origin in their couple throw a significant -and positive- result (Lazzaro \& Frateschi, 2017). The explanation to this can be because flamenco is a common hobby for the couple and, therefore, it can be a recurrent plan.

Concerning the variables that are characteristic of the individual's behavior, it has been identified that those individuals that attend live shows concerning other music genres also attend more often the flamenco ones. This can be related to the "cultural omnivores" idea (Peterson, 1992; Noya, 1998; Ariño, 2007; Warde, Wright \& Gayo-Cal, 2007). In this case, according to the categories made by Peterson and Kern (1996), there can be two types of cultural omnivores: the highbrow omnivores and the low omnivores. The first ones have tastes that range from the highest culture to the popular culture, while the second ones, despite having a wide range of tastes, often consume cultural assets related to popular culture (Prieto \& Fernández, 2000; FernándezRodríguez \& Heikkilä, 2011).

Lastly, from all the elements that may have an effect on the creation of the work, the only significant one in a positive way on the frequency of attendance is the consideration of the performer to be essential to the work.

The importance that the performer has on flamenco can be observed in the following assertion valued by flamenco consumers: "Please, denote the level of agreement/disagreement [from 1 to 7, being 1 "totally disagree" and 7 "totally agree"] according to the following assertion: when you attend a flamenco live show, the decision is made according to the performer that will perform". In the interpretation of the data, those individuals who valuated from 1 to 3 were considered to "totally disagree", "indifferent" with a 4 and "totally agree" those who valued from 5 to 7 . We can observe how $84.58 \%$ of the consumers agree with the given assertion.

With all this, it is empirically shown how the key figure, both in the valuation of the flamenco work (Heredia-Carroza et al., Forthcoming) and in the attendance frequency to live flamenco shows, is the performer (Throsby, 1983). Nevertheless, such importance has neither a retribution (Pitt, 2010; Meiseberg, 2014) nor protection, according to its importance by part of the main instrument given by the market: Copyright (de Román, 2003; Towse, 2007; HerediaCarroza, Palma \& Aguado, 2017). According to Heredia-Carroza et al. (2019c):

Flamenco is a shared practice, which, besides all creative agents, needs active listening, a sense of community, and a history. Due to its oral and performance traditions, these aspects are reflected mainly in the externalization of the work. For these reasons, improvement of the performer's situation in legal and economic terms would encourage creative freedom and would enrich the flamenco culture. It would allow the existence of works with many performers. The creation process of given works would have a common segment -the composition by the author- and a differentiated one -the externalization carried out by the performers. (p.355)

\section{Conclusions.}

In this article, we analyze the determinants for the frequency of attendance to flamenco live shows. The first contribution of the study has been its empirical strategy: firstly, we study on existing literature about cultural participation and cultural economics; secondly, we continue with several interviews to flamenco and the Spanish music industry experts, and finally, we build a unique database ad hoc through 580 surveys made to people that consider themselves to be "consumers of flamenco".

On the other hand, the estimation of the econometric model has allowed to determine that the sociodemographic variables, age and educational level, have a significant relation; the flamenco cultural capital of the individual has a positive and significant effect, and the performer 
is the only aspect of the flamenco work that has a significant and positive effect on the frequency of attendance.

From the results obtained, there are some ideas that can be detached for future cultural politics. Specifically, in Andalusia, the Consejo de la Agencia de la Defensa de la Competencia de Andalucía in 2017 uttered about the need for a change in flamenco policies, as it identified that the problem of non-attendance or the lower frequency of attendance was not due to the nonexistence of shows (Palma et al., 2017), but because of the lack of demand policies (Report N $4 / 2017$ on the draft order establishing the regulatory bases for awarding grants, under competitive conditions, for the promotion of the professional environment of flamenco in Andalusia). In this sense, it would also be necessary to question which role has flamenco in the educational institutions, in order to create a knowledge base about it that could be developed as a hobby in the future.

Finally, in relation to the studies carried out by Heredia-Carroza, Palma \& Aguado (2017) it can be observed how the figure of the performer in flamenco is fundamental. Both in terms of cultural level given to the flamenco work and the effect that influences the frequency of attendance to flamenco live shows by the consumers.

\section{Acknowledgments.}

The authors are grateful to Ms. Laura Llamas and MSc. Laura Díaz for many helpful discussions and comments, as well as to all the interviewed experts, the organizations, which disclosed the survey: Flama. La guia del Flamenco, Centro Andaluz de Documentación del Flamenco and the website Promocionmusical.com, and finally to the people who took the survey.

\section{Ethical statement.}

This article meets the requirements of compliance with Ethical Standards. The authors reported no potential conflict of interest. All the interviewed experts have signed an informed consent.

\section{References}

Agencia de la Defensa de la Competencia de Andalucía (2017). Informe N4/2017 sobre el proyecto de orden por la que se establecen las bases reguladoras de concesión de subvenciones en régimen de concurrencia competitiva, para la promoción del tejido profesional del flamenco en Andalucía. Retrieved from:

http://www.juntadeandalucia.es/defensacompetencia/sites/all/themes/competencia/file s/pdfs/Informe\%20N\%2004\%202017.pdf.

Aguado, L.F., \& Palma, L. (2015). Factores que limitan la participación cultural. Una mirada desde la economía de la cultura [Factors that limit cultural participation. A look from the economy of culture]. Revista de Ciencias Sociales, 21(1), 58-71.

Andrade, D.L. (2016). Determinantes de la asistencia a museos en Colombia. Una perspectiva desde la Economía de la Cultura [Determinants of assistance to museums in Colombia. A perspective from the Economy of Culture]. Dissertation. Universidad de Sevilla.

Aoyama, Y. (2007). The role of consumption and globalization in a cultural industry: The Case of Flamenco. Geoforum, 38(1), 103-113. DOI: 10.1016/j.geoforum.2006.07.004. 
Arboleda, A.M., \& González, J.F. (2016). Creating a competitive advantage: the exoticism of tango and salsa from Cali, Colombia. International Journal of Arts Managment, 19(1), $42-53$.

Ariño, A. (2007). Música, democratización y omnivoridad [Music, democratization and omnivority]. Política y Sociedad, 44 (3), 131-150.

Ateca-Amestoy, V. (2008). Determining heterogeneous behavior for theater attendance. Journal of Cultural Economics, 32(2), 127-151. DOI: 10.1007/s10824-008-9065-z.

Ateca-Amestoy, V. (2009). El capital humano como determinante del consumo cultural [Human capital as a determinant of cultural consumption]. Estudios de Economía Aplicada, 27(1), 89-112.

Aoyama, Y. (2009). Artist, Tourists, and the State: Cultural Tourism and the Flamenco Industry in Andalusia, Spain. International Journal of Urban and Regional Research, 33(1), 80104. DOI: $10.1111 / \mathrm{j} .1468-2427.2009 .00846 . x$.

Au, W. T., Ho, G., \& Chan, K.W.C. (2016). An Empirical Investigation of the Arts Audience Experience Index. Empirical Studies of the Arts, 35(1), 27-46. DOI: $10.1177 / 0276237415625259$.

Bande, R., \& Karanassou, M. (2013). The natural rate of unemployment hypothesis and the evolution of regional disparities in Spanish unemployment. Urban Studies. 50(10), 20442062. DOI: $10.1177 / 0042098013477695$.

Bermúdez, J.A., Medina, L.M., \& Aguado, L.F. (2016). La decisión de escuchar música grabada en Colombia. Un enfoque microeconométrico [The decision to listen to recorded music in Colombia. A microeconometric approach.]. Revista de Métodos Cuantitativos para la Economía y la Empresa, 21, 21-38.

Borowiecki, K.J., \& Marvao, C. (2017). May I have this dance? Dance participation and attendance in Denmark. Cultural Trends, 26(2), 155-167. DOI: 10.1080/09548963.2017.1323849.

Borra, C., \& Gómez, F. (2012). Satisfacción laboral y salario: ¿compensa la renta laboral las condiciones no monetarias del trabajo? [Labor satisfaction and salary: does labor income compensate for non-monetary conditions of work?] Revista de Economía Aplicada, 20 (60), 25-51.

Bourdieu, P. (1984). Distinction. Cambridge, MA: Harvard University Press.

Bürkner, H.J., \& Lange, B. (2017). Sonic capital and inependent urban music production: Analysing value creation and 'trial and error' in the digital age. City, Culture and Society, 10, 33-40. DOI: 10.1016/j.ccs.2017.04.002.

Chan, M.K., Au, W.T., Ying, C. (2016). Developing Validating a Theater Experience Scale. Empirical Studies of the Arts, 35(2), 169-193. DOI: 10.1177/0276237416662737.

Choi, A.S., Papandrea, F., \& Bennett, J. (2007). Assessing cultural values: developing an attitudinal scale. Journal of Cultural Economics, 31(4), 311-335. DOI: 10.1007/s10824007-9045-8. 
Cruces, C. (2001). El flamenco como Patrimonio. Anotaciones a la Declaración de la voz de la Niña de los Peines como bien de interés cultural. Sevilla: Bienal de Arte Flamenco.

Cuenca, M. (2016). Development of young opera Audiences. Reflections on the role of the artistic program. Cuadernos de Gestión, 17(1), 125-146. DOI: 10.5295/cdg.140492mc.

De Román, R. (2003) Obras musicales, compositores, intérpretes y nuevas tecnologías [Musical works, composers, performers and new technologies]. Madrid: REUS.

De Sancha-Navarro, J.M., Palma, L., Oliver-Alfonso M.D. (2019). Explanatory factors of university student participation in flamenco. Economics \& Sociology, 12(4): 130-148. DOI:10.14254/2071-789X.2019/12-4/8.

Dimoulas, C.A., Kalliris, G.M., Chatzara, E.G., Tsipas, N.K., \& Papanikolaou, G.V. (2014). Audiovisual production, restoration-archiving and content management methods to preserve local tradition and folkloric heritage. Journal of Cultural Heritage, 15(3), 234241.

Di Tella, R., MacCulloch, R.J., \& Oswald, A.J. (2001). Preferences over inflation and unemployment: evidence from surveys of happiness. The American Economic Review, 91 (1), 335-341.

Falk, M., \& Katz-Guerro, T. (2016). Cultural participation in Euroope: Can we identify common determinants? Journal of Cultural Economics, 40(2), 127-162. DOI: 10.1007/s10824015-9242-9.

Fernández, C.J., \& Heikkilä, R. (2011). El debate sobre el omnivorismo cultural. Una aproximación a nuevas tendencias en sociología del consumo [The debate on cultural omnivorism. An approach to new trends in consumer sociology]. Revista Internacional de Sociología (RIS), 69 (3), 585-606. DOI: 10.3989/ris.2010.04.15.

Ferrer-i-Carbonell, A., \& Frijters, P. (2004). How important is methodology for the estimates of the determinants of happiness. Economic Journal, 114, 641-659.

Guccio, C., Lisi, D., Martorana, M., \& Mignosa, A. (2017). On the role of cultural participation in tourism destination performance: an assessment using robust conditional efficiency approach. Journal of Cultural Economics, 41(2), 129-154. DOI: 10.1007/s10824-0179295-z.

Hadida, A.L. (2010). Commercial Success and Artistic Recognition of Motion Picture Projects. Journal of Cultural Economics, 34(1), 45-80. DOI: 10.1007/s10824-009-9109-z.

Hallmann, K., Muñiz, C., Breuer, C., Dallmeyer, S., \& Metz, M. (2017). Leisure participation: modelling the decision to engage in sports and culture. Journal of Cultural Economics, 41(4), 467-487.

Han, W., Huang, C., \& Garfinkel, I. (2003). The importance of family structure and family income on family's educational expenditure and children's college attendance. Journal of Family Issues, 24(6), 753-786. DOI: 10.1177/0192513X03254518. 
Helliwell, J.F., \& Huang, H. (2008). How's your government? International evidence linking good government and Well-Being. Cambridge University Press. DOI: $10.1017 / \mathrm{S} 0007123042000306$.

Heredia-Carroza, J., Palma Martos, L., \& Aguado, L.F. (2017). Originalidad Subjetiva y Copyright. El caso del flamenco en España [Creative Substance and Copyright. The case of flamenco in Spain]. Revista Andaluza de Ciencias Sociales, 16, 175-194. DOI: 10.12795/anduli.2017.i16.10.

Heredia-Carroza, J., Pulido, N., \& Palma, L. (July, 2017). Where does the creativity reside in Europe? An analysis of the determinants of the clustering of the European regions. XXXI Congreso Internacional de Economía Aplicada. Lisboa, Portugal.

Heredia-Carroza, J., Palma, L. \& Aguado, L. F. (2019a). Song, performance and authorship: The case of flamenco in Spain. Trames. A Journal of the Humanities and Social Sciences, 23 (1), 3-14. DOI: 10.3176/tr.2019.1.01.

Heredia-Carroza, J., Palma, L., \& Aguado, L. F., (2019b). Flamenco y Derechos de Autor. El caso de Camarón de la Isla. Arbor, 195(791), a496. DOI: 10.3989/arbor.2019.791n1009.

Heredia-Carroza, J., Palma, L., \& Aguado, L.F., (2019c). Why Does Copyright Ignore Performers? The Case of Flamenco in Spain. The Journal of Arts Management, Law and Society, 49(5), 347-364. DOI: 10.1080/10632921.2019.1646682.

Heredia-Carroza, J. (2019). Flamenco Performer's Perceived Value: Development of a Measurement Index. Scientific Annals of Economics and Business. DOI: 10.2478/saeb2019-0017.

Heredia-Carroza, J., Palma, L., \& Aguado, L.F. (Fothcoming). How to measure Intangible Cultural Heritage Value? The case of flamenco in Spain. Empirical Studies of the Arts.

Hernando, E., \& Campo, S. (2017). Does the Artist's Name Influence the Perceived Value of an Art Work? International Journal of Arts Management, 19(2), 49-58.

Hill, E.J. (2005). Work-Family facilitation and conflict, working fathers and mothers. Work-Faily stressors and support. Journal of Family Issues, 26(6), 793-819. DOI: $10.1177 / 0192513$ X05277542.

Holbrook, M.B., \& Hirschman, E. (1982). The experiential aspects of consumption: consumption fantasies, feelings and fun. Journal of Consumer Research, 9, 132-140.

Holbrook, M.B. (1999). Consumer value: a framework for analysis and research. Interpretative market research series. London and New York: Routledge.

Icazuriaga, J., Cuadrado, M., \& Miquel, M.J. (2016, September). Analysing Perceived Value, Satisfaction and Purchase Intention in the Music Industry. $7^{\text {th }}$ Vienna Music Business Research Days, Viena, Austria.

Infante, B. (1980). Orígenes de lo Flamenco y Secreto del Cante Jondo [Origins of flamenco and secret of cante jondo]. Sevilla: Junta de Andalucía, Consejería de Cultura. 
Jiménez-Martín, S., Juanmarti, A., \& Vall, J. (2019). Great Recession and sibability insurance in Spain. Empirical Economics, 56(5), 1623-1645. DOI: 10.1007/s00181-017-1396-1.

Klamer, A. (2003). A Pragmatic View on Values in Economics. Journal of Economic Methodology, 10(2), 1-24. DOI: 10.1080/1350178032000071075.

Lazzaro, E., \& Frateschi, C. (2017). Couples' arts participation: assessing individual and joint time use. Journal of Cultural Economics, 41, 47-69. DOI: 10.1007/s10824-015-9264-3.

Leguina, A., \& Miles, A. (2017). Fields of participation and lifestyle in England: revealing the regional dimension from a reanalysis of the taking part survey using multiple factor analysis. Cultural Trends, 26(1), 4-17. DOI: 10.1080/09548963.2017.1274356.

Levinson, J. (2015). Musical Concerns, Essays in Philosophy of Music. Oxford: Oxford University Press.

Levy-Garboua, L., \& Montmarquette, C. (1996). A microeconometric study of theatre demand. Journal of Cultural Economics, 20, 25-50.

Lundy, D. E. \& Smith, J. L. (2016). It's tough to be a Critic: Professional vs. Non-professional Music Judgment. Empirical Studies of the Arts, 35(2), 139-168. DOI: $10.1177 / 0276237416661989$.

Malthouse, E.C., \& Calder, B.J., (2002). Measuring Newspaper Readership: a qualitative variable approach. The International Journal on Media Management, 4(4), 248-260.

Manuel, P. (2010). Composition, Authorship and Ownership in Flamenco, Past and Present. Ethnomusicology, 54 (1), 106-135.

Meiseberg, B. (2014). Trust the artist versus trust the tale: performance implications of talent and self-marketing in folk music. Journal of Cultural Economics, 38(1), 9-42. DOI: $10.1007 / \mathrm{s} 10824-012-9196-0$.

Michael, R., \& Becker, G.S. (1973). On the new theory of consumer behavior. Swedish Journal of Economics, 75(4), 378-396.

Montoro-Pons, J.D., \& Cuadrado-García, M. (2011). Live and prerecorded popular music consumption. Journal of Cultural Economics, 35(1), 19-48. DOI: 10.1007/s10824-0109130-2.

Noya, F.J. (1998). Omnívoros sociables: consumo y capital relacional en España [Sociable omnivores: consumption and relational capital in Spain]. Sociológica: Revista de pensamiento social, 3, 69-92.

Palma, L., \& Aguado, L. F. (2011). ¿Debe el Estado financiar las artes y la cultura? Revisión de literatura. [Should the State finance the arts and culture? And literatura review] Economia E Sociedade, 20(1), 195-228. DOI:10.1590/S0104-06182011000100008.

Palma, M.L., Palma, L., \& Aguado, L. (2013). Determinants of cultural and popular celebration attendace: the case study of Seville Spring Fiestas. Journal of Cultural Economics, 37, 87-107. 
Palma, L., Palma, M.L., Rodríguez, A., Martín, J.L., \& Cascajo, I. (2017). Live flamenco in Spain: a dynamic analysis of supply, with managerial implications. International Journal of Arts Management, 19(3), 1-14.

Peterson, R.A. (1992). Understanding Audience Segmentation: From Elite and Mass to Omnivore and Univore. Poetics, 21(4), 243-258.

Peterson, R.A., \& Kern, R.M. (1996). Changing Highbrow Taste: From Snob to Omnivore. American Sociological Review, 61(5), 900-909.

Pitt, I.L. (2010). Superstars effects on royalty income in a performing rights organization. Journal of Cultural Economics, 34(3), 219-236. DOI: 10.1007/s10824-010-9123-1.

Prieto, J., \& Fernández, V. (2000). Are Popular and Classical Music Listeners the Same People? Journal of Cultural Economics, 24, 147-164. DOI: 10.1023/A:1007620605785.

Rebollo-Sanz, Y., \& García-Pérez, J.I. (2015). Are unemployment benefits harmful to the stability of working careers? The case of Spain. SERIEs, 6(1), 1-41. DOI: 10.1007/s13209-0140120-z.

Romero, J. (1996). La otra historia del flamenco [The other history of flamenco]. Sevilla: Junta de Andalucía.

Rosón, T. (2010). El Flamenco como obra musical, coreográfica y escénica. Las obras originales y derivadas: versiones, arreglos y utilización de las obras [Flamenco as a musical, choreographic and scenic work. The original and derivative works: versions, arrangements and use of the works]. In: Castilla, M. (Ed.), El Flamenco y los Derechos de Autor, 23-38. Madrid: REUS, 2010:23-38.

Sala, H., \& Trivin, P. (2014). Labour market dynamics in Spanish regions: evaluating asymmetries in troublesome times. SERIEs, 5(2-3), 197-221. DOI: 10.1007/s13209-0140106-x.

Steingress, G. (2007). Flamenco postmoderno: entre tradición y heterodoxia: un diagnóstico sociomusicológico (escritos 1989-2006) [Postmodern flamenco: between tradition and heterodoxy: a sociomusical diagnosis (writings 1989-2006)]. Signatura, Sevilla.

Throsby, D. (1983). Perception of quality in demand for the theatre. In: Hendon, W., \& Shanahan, J., Economics of cultural decisions. Cambridge: Abt Books.

Towse, R. (2007). The Singer or the Song? Developments in Performers' Rights from the Perspective of a Cultural Economist. Erasmus University Rotterdam.

Warde, A., Wright, D., \& Gayo-Cal, M. (2007). Understanding Cultural Omnivorousness: Or, the Myth of the Cultural Omnivore. Cultural Sociology, 1(2), 143-164.

Werck, K., \& Heyndels, B. (2007). Programmatic choices and the demand for theatre: The case of Flemish theatres. Journal of Cultural Economics, 31, 25-41.

Withers, G. (1980). Unbalanced growth and the demand for performing arts: An econometric analysis. Southern Economic Journal, 46(3), 735-742. 
Zanola (2010). Major influences on circus attendance. Empirical Economics, 38(1), 159-170. DOI: $10.1007 / \mathrm{s} 00181-009-0260-3$.

Zieba, M., \& O'Hagan, H. (2010) Output Characteristics and Other Determinants of Theatre Attendance: An Econometric Analysis of German Data (2010), Applied Economics Quarterly, 56(2), 147-174. 
Appendix I. Panel of interviewed experts.

\begin{tabular}{|c|c|c|}
\hline \multirow{6}{*}{$\begin{array}{l}\text { PERFORMERS AND } \\
\text { AUTHORS }^{1}\end{array}$} & José Mercé & $\begin{array}{l}\text { Award Masters of Mediterranean Music from the } \\
\text { Mediterranean Music Insitute (MMI) of Berklee College of } \\
\text { Music. Medalla de Andalucía } 2 \text { 2010. } 1 \text { Double Platinum } \\
\text { Record, 2 Platinum records and } 2 \text { Golden records. }\end{array}$ \\
\hline & Tomatito & $\begin{array}{l}\text { Medalla de Oro al Mérito en las Bellas } \text { Artes }^{3} 2016 \text {. Winner of } \\
6 \text { Latin Grammy. }\end{array}$ \\
\hline & Marina Heredia & $\begin{array}{l}\text { Giraldillo }^{4} \text { for cante 2016. Award Mejor disco de Cante } \\
\text { Flamenco } 2010 \text {, by the Crítica Nacional de Flamenco. }\end{array}$ \\
\hline & Paco Cepero & Medalla de Oro al Mérito en las Bellas Artes 2003. \\
\hline & Rocío Márquez & $\begin{array}{l}\text { Winner of the Lámpara Minera }{ }^{5} \text { in } 2008 \text { and of the Giraldillo } \\
\text { for innovation } 2016 .\end{array}$ \\
\hline & Barullo & $\begin{array}{l}\text { Winner of the Concurso Nacional de } \text { Córdoba }^{6} 2016 \text {. Baile } \\
\text { Category. }\end{array}$ \\
\hline $\begin{array}{l}\text { POLITICIAN AND } \\
\text { RESEARCHER }\end{array}$ & $\begin{array}{l}\text { Dr. Juan Manuel } \\
\text { Suárez Japón }\end{array}$ & $\begin{array}{l}\text { Culture and Environment Counselor of the Junta de Andalucía } \\
\text { in 1990-1994. Professor of Human Goegraphy at the } \\
\text { Universidad Pablo de Olavide. }\end{array}$ \\
\hline \multirow[b]{2}{*}{$\begin{array}{l}\text { REPRESENTATIVES } \\
\text { SGAE }^{7}\end{array}$} & D. Javier Losada Calvo & $\begin{array}{l}\text { Vice president of Pequeño Derecho of SGAE. Member of the } \\
\text { Consejo de Administración of the AIE (1999-2012). }\end{array}$ \\
\hline & $\begin{array}{l}\text { D. José Manuel } \\
\text { Gamboa }\end{array}$ & $\begin{array}{l}\text { Spanish journalist, writer and musical producer, specialized in } \\
\text { Flamenco. Currently, is the technical music analyst in the } \\
\text { Flamenco specialty and a member of the academic group of the } \\
\text { Cátedra de Flamencología de Jerez de la Frontera. }\end{array}$ \\
\hline \multirow{2}{*}{$\begin{array}{l}\text { REPRESENTATIVES } \\
\text { AIE }^{8}\end{array}$} & $\begin{array}{l}\text { D. Álvaro Hernández- } \\
\text { Pizón } \\
\end{array}$ & Director of legal Consultancy and Collection Strategy. \\
\hline & D. Pedro Rivas Prieto & Attorney of AIE. \\
\hline \multirow{3}{*}{ CULTURAL MANAGERS } & $\begin{array}{l}\text { D. Cristóbal Ortega } \\
\text { Martos }\end{array}$ & Artistic director of the Bienal de Sevilla ${ }^{9}$ since 2014. \\
\hline & $\begin{array}{c}\text { Dña. Isamay } \\
\text { Benavente Ferrera }\end{array}$ & Artistic director of the Festival de Jerez de la Frontera ${ }^{10}$. \\
\hline & $\begin{array}{l}\text { D. Manuel Herrera } \\
\text { Rodas }\end{array}$ & $\begin{array}{l}\text { Artistic director of the Jueves flamencos organized by the } \\
\text { Fundación Cajasol }{ }^{11} \text { and member of the Consejo Asesor de la } \\
\text { Bienal de Sevilla. He was also the artistic director of the Bienal } \\
\text { de Sevilla in 1997-2006. }\end{array}$ \\
\hline $\begin{array}{l}\text { CENTRO ANDALUZ DE } \\
\text { DOCUMENTACIÓN DEL } \\
\text { FLAMENCO (CADF) }\end{array}$ & $\begin{array}{l}\text { Dra. Ana María } \\
\text { Tenorio Notario }\end{array}$ & Manager of the CADF documentation department \\
\hline
\end{tabular}

Notes:

${ }^{1}$ All of them are performers and composers of many of the works they participate in.

${ }^{2}$ Honorary title created by the Junta de Andalucía in 1985, whose purpose is to recognize "the exceptional or extraordinary actions, services and merits carried out in times of peace by Andalusian, Spanish or foreign citizens, groups or organizations" that represent "the exercise of individual or collective virtues that refer to solidarity and work in favor of the rest of citizens". This is regulated by the Decree 117/85 of June 5 th

${ }^{3}$ It is a medal that the Ministry of Culture of Spain awards to the people or institutions that stand out in the literary, dramatic, musical, choreographic and interpretative fields.

${ }^{4}$ Recognition awarded by the Flamenco Bienal de Sevilla.

${ }^{5}$ Recognition awarded by the Festival Internacional del Cante de las Minas, celebrated every year in the municipality of La Unión (in the Region of Murcia).

${ }^{6}$ Recognition awarded by the Concurso Nacional de Arte Flamenco de Córdoba, triennal contest celebrated in Córdoba (Spain) since 1956.

${ }^{7}$ Sociedad General de Autores y Editores de España. For more information: http://www.sgae.es/esES/SitePages/index.aspx 
${ }^{8}$ Sociedad de Artistas, Intérpretes o Ejecutantes de España. For more information: https://www.aie.es/

${ }^{9}$ The Bienal is the great international event in the world of flamenco. It is celebrated every two years in Sevilla, where amateurs and professionals of the sector from around the world meet. For more information: labienal.com.

${ }^{10}$ Jerez de la Frontera is considered as one of the most important geographic places by the flamenco experts. The city has a well-defined style and idiosyncrasy, being its Festival one of the most important offered by the market. For more information: http://www.jerez.es/webs_municipales/festival_jerez/

${ }^{11}$ Cycle of concerts and recitals of Flamenco organized by the Fundación Cajasol. For more information: https://fundacioncajasol.com/tag/jueves-flamencos/

${ }^{12}$ Created in 1987 for the conservation of Flamenco by means of an important work of recovery, cataloging and diffusion of the Andalusian cultural heritage. For more information: http://www.juntadeandalucia.es/cultura/centroandaluzflamenco/

\section{Appendix II. Means used to listen to flamenco music.}

The question asked in the survey was: The mean you normally use to listen to flamenco is:

Figure 1. Percentage of means used to listen to flamenco.

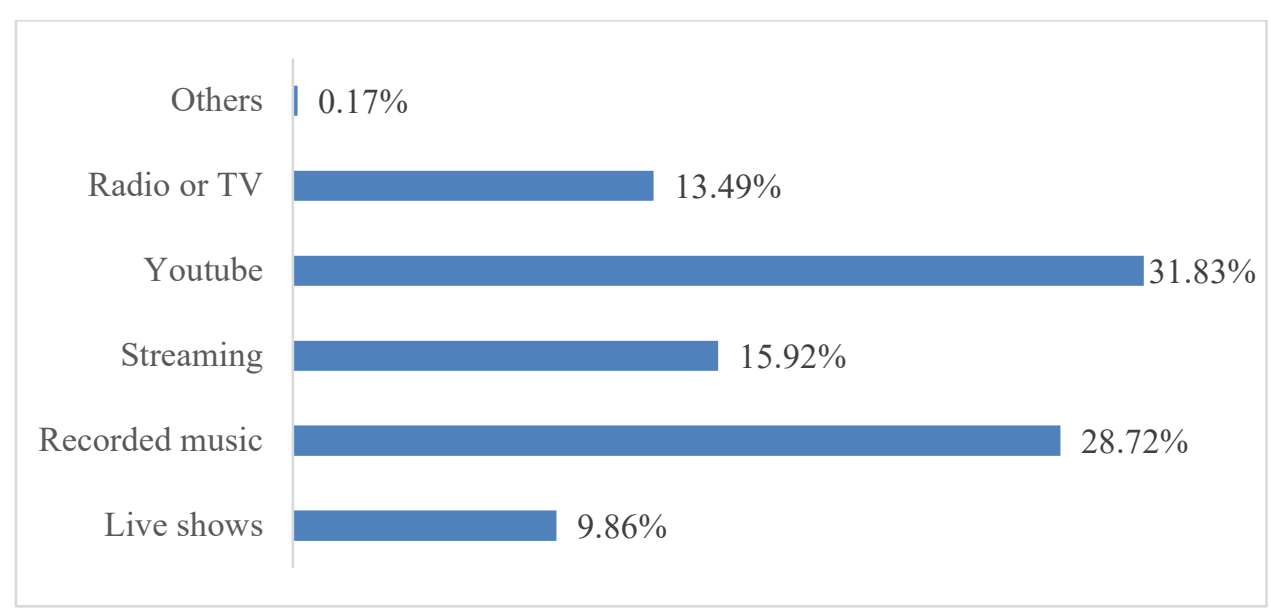

Source: Own elaboration. 